\title{
Lessons from Foreign Owned Spaza Shops in South African Townships
}

\author{
Byron Lamb, Lindiwe Nqobile Kunene* and Nomalizo Florence Dyili
}

\author{
University of KwaZulu-Natal, South Africa
}

\begin{abstract}
In 2014, the World Bank pronounced how the informal sector is probably responsible for half of the GDP in developing countries. This sector can no longer be ignored as it is embedded in most developing countries' economies. In a country like South Africa, the informal sector is a gateway to economic freedom where the historically deprived groups were left behind and could not participate in the formal economic sectors, as they would have liked. This was due to racially skewed policies of the apartheid regime. The country saw black racial groups marginalised from acquiring appropriate skills, education and resources to allow them to participate in the formal economy. The barrier to entry into formal economies resulted in the significant rise of the informal economy. One of the most prevalent business forms in this sector has been Spaza Shops. In fact, in South Africa, Spaza Shops have become synonymous with the informal sector. Post-apartheid, with the opening of the country's borders over the years, there has been an increase in foreign owned Spaza Shops both legally and illegally, at the expense of locally owned ones. Using an exploratory research design, this paper sought to uncover various practices and procedures that have been accredited to the success of foreign owned Spaza's in townships. Through qualitative engagement with relevant literature published over a period of six years, a relationship between foreign owned businesses and locally owned businesses in the townships of South Africa was investigated. The study outcomes identified motives for increased and successful foreign owned businesses in townships. These are Networking and Economies of Scales; Socio-Economic Motivators; Geographic Location; Financial Management, Entrepreneurial Orientation and Business practice. All of these motives are seen as equally important and can be used to upskill and motivate local informal traders to be as competitive within the township economy.
\end{abstract}

Keywords: Entrepreneurship, apartheid, xenophobia, innovation and township economy.

\section{INTRODUCTION}

Small, home-based, micro, informal enterprises such as 'Spaza Shops' and tuck shops, are synonymous with low income residential areas. This is a phenomenon experienced, the world over, but unequivocally so apropos the context of South African townships. In a post-Apartheid era, there has been an influx of immigrants entering South Africa resulting in a rise of activity in the informal sector. As foreign nationals start to engage in informal trade and in the economy, significant changes have been observed. This study seeks to analyse the growth that foreign-run Spaza Shops have had in comparison to South African businesses. Their growth and ability to be the preferred suppliers of goods in the township suggests that there may be lessons of importance that could be learnt by local Spaza Shop owners. The problem at hand is the underperformance of, and subsequent closing down phenomenon of locally run township businesses as opposed to foreign owned entities.

This paper makes use of an amalgamation of empirical evidence and theoretical literature to critically evaluate: the asymmetrical business culture; business practices; entrepreneur orientation, economic activity of

*Address correspondence to this author at the University of KwaZulu-Natal, School of Management Information \& Governance, Room M1-113, Private Bag X 54001, Durban, 4001, South Africa; Tel: +2731-260 7152;

E-mail: kunenel3@ukzn.ac.za the entrepreneurs; and the respective business stakeholders of these informal shops. This review will facilitate a clear reflection on the nature and environment of the industry and how it can be developed and sustained in South Africa. Moreover, it will discuss and postulate around the topics of: conflicts between locals and foreign nationals, both in business and physical aspects; the absolute government regulation and legislation; as well as the challenges and limitations facing these entrepreneurs and the trade as a whole. This enquiry concludes with a proposal of recommendations as to how local, informal entrepreneurs can go about improving their performance, generating new opportunities, and implementing best business practices for their entities through lessons learnt from foreign business competitors.

\section{BACKGROUND}

Start-ups, self-employment and entrepreneurship open up numerous opportunities for growth and development for socio-economic progress. Since the end of apartheid in 1994, the observed substantial economic improvement in South Africa, is admirable. It is acknowledged and well documented that informal businesses constitute a profusion of entrepreneurial activities (Preisendorfer, Bitz, and Bezuidenhout, 2012). Micro-entrepreneurial endeavours and 
opportunities within the informal sector are often cited as stemming from the apartheid era when commercial prospects for black entrepreneurs were constrained. From the mid 1990's, South Africa has seen an extensive reallocation of income distribution towards low-income households (Ligthelm, 2011). This has contributed to a significant increase in economic growth and consumer spending within townships. Unfortunately, this is not considered or included in the calculation of the country's GDP. Trade industry sources like 'Spazanews.co.za', assert that this sector comprises of more than 100000 establishments with a collective turnover of R7-billion, annually (Liedeman, Charman, Piper, and Peterson, 2013).

In this research paper, emphasis is placed on Spaza Shops amidst a plethora of informal trade concepts like "chop" shops as an example, because they form the majority of the informal market. 'Spaza' is a generic term derived from the colloquial isiZulu word, meaning 'hidden' or 'imitation of a real store' (Charman, Petersen, and Piper, 2012). Over time, these microconvenience stores that originated by serving as personal and retail services for lower income groups within townships, began to shape shift as the need for their existence grew. Historically, Spaza Shops started out in the homes of township inhabitants with few items being sold, progressively evolving as the market developed in size (Sustainable Livelihoods Foundation (SDF), 2012). The aim was convenience in assisting communities with their immediate needs (Meyer, Meyer and Molefe, 2016). These shops brought additional income to owners and provided availability of items demanded by citizens residing long distances from major shopping areas or wholesale retailers. The SDF (2012) also postulates that the majority of Spaza Shops owned locally remain female, in-house run shops, whilst those administered by foreign nationals are run by males, and operate from an extended room or rented premises. According to Fatoki (2014) micro enterprises that are male run tend to be profit-driven, whereas the ones run by females are more inclined to be motivated by social factors. Most Spaza Shops do not comply with municipal rules, legislation and consequently, remain unregistered businesses.

Since 2005, competition between foreign and local informal commerce has become largely pronounced. Liedeman et al. (2013) cited a study by Charman which stipulated that almost $50 \%$ of informal businesses had become foreign run, indicative of a strong presence of immigrant-run businesses. The opportunity-motivated outlook associated with foreign owned business practice, has been poised to constantly outperform the survivalist mode linked with the locally owned class, estimated to be $75 \%$ of all businesses (Charman et al., 2012). Foreign dominance fuels the rivalry of South African shopkeepers against immigrants, and has created a culture of xenophobia and heightened social conflict.

It is important to bring up a few caveats concerning this study, including the various datasets being analysed. The ability to observe immigration and business start-up patterns will always remain incomplete due to administrative errors. Furthermore, there exists a multitude of factors related to the closure and underperformance of locally owned township businesses. Aspects such as health and well-being; government legislation; and business environment must be taken into consideration. Available figures could underestimate the level of entrepreneurial activities due to standard error in data sources and or deduction of the authors of these articles. Another constraint is that the actual size and composition of the Spaza Shop market in South Africa is not fully understood. Many settlements were not recorded by Statistics SA in the recent decade, and true population samples have diverged from what was recorded by the 2001 master sample census (World Bank Group, 2014).

This paper's analysis focuses on the following points: ownership dynamics; business nature, culture, and practices; entrepreneurial and stakeholder activities; xenophobic conflict; government regulation; sustainability; barriers to entry; among others. At the forefront of the aims of the paper is a question of prospects and guidelines required for local entrepreneurs to succeed in contrast to the hegemony of foreign owned shops. The next section introduces the literature within this field of study. It introduces the eclectic research field on successful start-ups and will begin the development of a debate. Research questions about defining characteristics of a successful business venture are not, by any means, new, they are merely documented mostly in developed countries such as the United States and Germany (Preisendorfer et al., 2012). This paper further aims is to integrate the aforementioned empirical research and studies conducted in South Africa and applied in the South African Township context.

\section{LITERATURE}

The topic under consideration is the differentiation between the performances of local informal township 


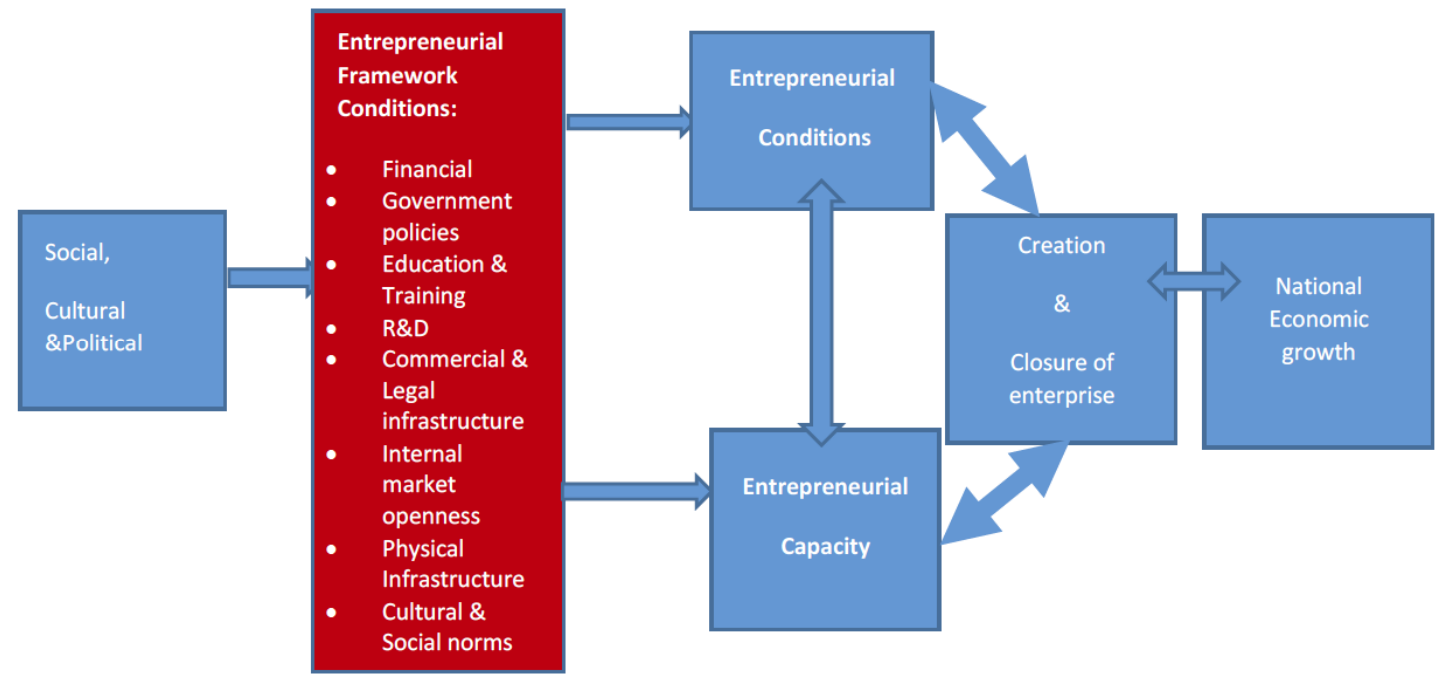

Figure 1: Entrepreneurial Framework Conditions.

Source: Kunene and Fields (2017:5).

businesses and that of businesses of foreign nationals. Of importance in the discourse, is the identification of constructs that can be applied universally by all in the township economy space in South Africa using a framework that supports entrepreneurial growth, which is the Global Economic Monitor (GEM) framework adapted by Kunene and Fields (2017).

This framework provides important factors that are relevant and vital in creating entrepreneurial entities that have an impact on the economy. Framework conditions are key in ensuring that entrepreneurial businesses play a significant role in National Economic Growth (Kunene and Fields, 2017). Though some may claim that Spaza Shops are not entrepreneurial businesses, it may be argued that by virtue of availing products demanded in places where there were no such products, they are fulfilling an opportunity, creating value not previously fulfilled; assuming both reward and risk by doing so. Encompassing these characteristics means that they actually are entrepreneurs (Van Aardt, Barros, Clearence, Janse van Rensberg, Radipere, Rankhumise, Venter and Visser, 2016). Neve and du Toit (2012), further assert that these businesses are of importance, as the social gap they fulfil forms part of entrepreneurial activity. 'Approximately 2.3 million people worked in the nonagricultural informal sector in 2013, (In 2018 it reached 2.9 million.) At about $17 \%$ of total employment, one in every six South Africans who work, works in the informal sector' (Fourie, 2018: Online). This strongly suggests that these entities are of significance to the South African Economy and the country's entrepreneurial activity.
An integral piece of literature, underpinning the fundamental purpose of this paper's research objectives, is an article published in 2013 by the Sustainable Livelihoods Foundation. Written by Liedeman, Charman, Piper and Peterson and the Sustainable Livelihoods Foundation Liedeman et al. (2013) the article examined the differences between South African run business models and the performance of foreign-run businesses, and interrogates this rapidly changing industry. The survey undertaken was focused on the township of Delft in Cape Town. Using methods such as an ethnographic study and geographic information systems (GIS) allowed for the distribution of foreign shops in the area to be mapped in order to determine the foothold of foreign owned enterprises in the Spaza Shop microeconomy. The paper argued that South African shopkeepers were not as successful as foreign owners due to the power of their market domination, their social networking skills, as well as their collective purchasing structures. The evaluation concluded with policy approaches, solutions to the phenomenon, and enlightened the reader of this fierce competitor within the sector.

A similar trend was noted by Basardien, Parker, Bayat, Friederich and Appoles (2014) in their analysis of the same phenomenon. There has been an increasing propensity for foreigners, specifically Somalian nationals, to become the dominant force in the informal economy. This report however focused on the Spaza market of Khayelitsha, Cape Town, and consisted of a survey sample of 352 operating entrepreneurs. This cross-sectional study made use of 
both qualitative and quantitative methodologies including surveys; interviews; focus groups; and statistical causality to determine relationships between variables and the nature of the informal market. Besides the raised additional issue of xenophobia, the piece highlighted factors, that they assert, are important for entrepreneurs in the township industry. These factors are entrepreneurial orientation and business practices. Their analysis finished off by defining the foreign businesses practice of pricing strategies, collective buying, and overall heightened financial management skill as reasons foreign nationals not only accomplish more, but infringe on the sustainability of locally-run shops and cause them to inevitably face closure.

Hutchinson and de Beer (2013) focused more on the aspect of sustainability and published an article exploring issues that limit the growth and existence of survivalist enterprises. Their paper made use of a primary-non-probability questionnaire to gather data from 108 participants and secondary data sources such as articles, reports, and academic foundations. Overall, it represented a quantitative and descriptive form of research methodology, asserting that the high failure rate of survivalist and micro South African informal businesses are due to both internal and external factors. They identified internal factors such as poor planning; inefficient networking; deficient business experience; insufficient education and training. External factors which contributed to early closure of South African entrepreneurial township businesses include a lack of services like governmental training and development programs. It was recapitulated that the empirical evidence from this study illustrates why the sustainability of local, informal sector, enterprises is being threatened.

The most recently written literature available for review on the topic is another article from the Sustainable Livelihoods Foundation, this time in association with Hartnack and Liedeman (2017). The research paper reiterated the above literature, and speaks to the contributory factors in the demise of informal businesses. The investigation looks at the period between 2010 and 2015, coincidently, in the township of Delft in Cape Town. The article suggests that South African businesses are unable to cope with, and respond to competition that they suddenly face in the township because they have to deal with more household shocks such as funerals; face a broader set of socio-economic challenges like crime; and face tougher regulatory environments, for example liquor trade laws which are harshly enforced by police.
Contemporaneous literature was compiled by Chikwendu Ezennia, Mutambara, and Indermun in 2015 focussed on informal businesses owned by foreign nationals in the province of KwaZulu-Natal, particularly Durban. The evaluation incisively explores the significance of the existence of foreign small informal enterprises as well as the encounters of violent attacks and the general social-economic problems they endure within South African townships. Chikwendu Ezennia et al. (2015) found a gap between authorities and foreign business owners in terms of provision of security; high rental charges; appropriate policy formulation; infrastructure; and broad-spectrum bureaucracy.

In 2014 Olawale Fatoki from the University of Limpopo concluded that foreign run informal businesses were significant to the economy. He classified these activities as immigrant entrepreneurship, crucial to economic growth and employment creation in South Africa (Fatoki, 2014). He attributed their success to networking; performance; access to finance and culture.

\section{METHODOLOGY}

To complete this research, literature analysis was used with the aim of identifying common practice used by foreign businesses. This was done to understand how foreign shop owners conduct their business that yield success in South African townships. Qualitative data was collected over a period of two weeks. This was completed as an exploratory desktop study.

The study sought to find literature on studies conducted in South Africa between the years 2011 and 2017. The aim was to select papers that had been published more than two years ago, allowing research transcripts to have a fair enough time to influence research and practice. For the desktop research activities, Google Scholar was utilised to source articles. The search keywords were aligned to the research objectives of the study and thus the following keywords were used:
1. Township enterprise
2. Township economy
3. Socio-Economy and township
4. Xenophobia and township business
5. Spaza Shops
6. Black owned Spaza Shops in the township 
Table 1: Presentation of Results

\begin{tabular}{|c|c|c|c|c|}
\hline $\begin{array}{c}\text { Entrepreneurial } \\
\text { Framework Conditions }\end{array}$ & Author \& Date & Title of study & Main Objective & Main Findings \\
\hline \multirow[t]{6}{*}{$\begin{array}{l}\text { Socio-economic, cultural } \\
\text { and political }\end{array}$} & Abdi (2011) & $\begin{array}{l}\text { Moving beyond xenophobia: } \\
\text { Structural violence, conflict } \\
\text { and encounters with the } \\
\text { 'other' Africans }\end{array}$ & $\begin{array}{l}\text { This study examined } \\
\text { contact, conflict and } \\
\text { cooperation between } \\
\text { South Africans and } \\
\text { Somalis, including Somali } \\
\text { owned Spaza Shops in } \\
\text { townships and informal } \\
\text { settlements. }\end{array}$ & $\begin{array}{l}\text { The study concludes } \\
\text { that violence against } \\
\text { migrants is rooted in } \\
\text { South Africa's } \\
\text { continuing structural } \\
\text { violence and communal } \\
\text { crisis, a condition } \\
\text { characterised by } \\
\text { tensions with } \\
\text { compatriots as well as } \\
\text { with newcomers. }\end{array}$ \\
\hline & $\begin{array}{l}\text { Neves and du Toit } \\
\text { (2012) }\end{array}$ & $\begin{array}{l}\text { Money and Sociality in South } \\
\text { Africa's informal economy. }\end{array}$ & $\begin{array}{l}\text { This study examined the } \\
\text { social dimensions of } \\
\text { money in South Africa's } \\
\text { economy by considering } \\
\text { the interplay of agency. }\end{array}$ & $\begin{array}{l}\text { The study finds that; In } \\
\text { the informal sector, } \\
\text { social considerations } \\
\text { shape and inform the } \\
\text { diverse objectives of } \\
\text { entrepreneurial } \\
\text { activities. }\end{array}$ \\
\hline & Fatoki (2014) & $\begin{array}{c}\text { Gender, Entrepreneurial } \\
\text { Motives and Performance } \\
\text { Satisfaction of Micro } \\
\text { Enterprises in South Africa }\end{array}$ & $\begin{array}{l}\text { This study examined } \\
\text { whether there are } \\
\text { significant gender } \\
\text { differences in the motives } \\
\text { and performance } \\
\text { satisfaction of micro } \\
\text { entrepreneurs. }\end{array}$ & $\begin{array}{l}\text { The results indicated } \\
\text { that male entrepreneurs } \\
\text { are motivated largely by } \\
\text { economic Factors, while } \\
\text { women entrepreneurs } \\
\text { are motivated by social } \\
\text { factors. }\end{array}$ \\
\hline & Piper and Yu (2016) & $\begin{array}{l}\text { Deconstructing 'the foreign': } \\
\text { The limits of citizenship for } \\
\text { explaining price competition } \\
\text { in the Spaza sector in South } \\
\text { Africa }\end{array}$ & $\begin{array}{c}\text { The study aims to } \\
\text { determine price } \\
\text { competitiveness of foreign } \\
\text { owned Spaza Shops } \\
\text { against South African } \\
\text { owned ones. }\end{array}$ & $\begin{array}{l}\text { The study finds that } \\
\text { business } \\
\text { competitiveness does } \\
\text { not correspond with } \\
\text { foreign or South African } \\
\text { businesses, but rather, } \\
\text { is influenced by product } \\
\text { specification dynamics } \\
\text { and location of the } \\
\text { enterprise. }\end{array}$ \\
\hline & $\begin{array}{l}\text { Chikwendu Ezennia, } \\
\text { Mutambara, and } \\
\text { Indermun (2015) }\end{array}$ & $\begin{array}{c}\text { Challenges Faced by } \\
\text { Foreign-owned Informal } \\
\text { Small Businesses in Durban, } \\
\text { South Africa }\end{array}$ & $\begin{array}{l}\text { The study explored the } \\
\text { significance of the } \\
\text { existence of foreign small } \\
\text { informal enterprises as } \\
\text { well as the encounters of } \\
\text { violent attacks and } \\
\text { generally the social- } \\
\text { economic problems } \\
\text { endured within South } \\
\text { African townships. }\end{array}$ & $\begin{array}{c}\text { The study found a gap } \\
\text { between authorities and } \\
\text { foreign business owners } \\
\text { in terms of: provision of } \\
\text { security; high rental } \\
\text { charges; appropriate } \\
\text { policy formulation; and } \\
\text { broad-spectrum } \\
\text { bureaucracy }\end{array}$ \\
\hline & $\begin{array}{l}\text { Kunene and Dyili } \\
\qquad(2014)\end{array}$ & $\begin{array}{c}\text { Socio-Economic Viability of } \\
\text { the Protex Business Hive } \\
\text { Infrastructure for the } \\
\text { KwaDabeka Township in } \\
\text { KwaZulu-Natal, South Africa }\end{array}$ & $\begin{array}{l}\text { This empirical study set } \\
\text { out to create solutions for } \\
\text { the growth and } \\
\text { development of social and } \\
\text { economic viability in the } \\
\text { KwaDabeka township. }\end{array}$ & $\begin{array}{l}\text { Results of the study } \\
\text { showed that lack of } \\
\text { skills and basic needs, } \\
\text { accelerated social ills } \\
\text { and poor health were } \\
\text { the cause for stagnant } \\
\text { growth in the townships. } \\
\text { Townships were still } \\
\text { experiencing abject } \\
\text { poverty and economic } \\
\text { stagnation as a direct } \\
\text { consequence of } \\
\text { apartheid. }\end{array}$ \\
\hline
\end{tabular}


(Table 1). Continued.

\begin{tabular}{|c|c|c|c|c|}
\hline $\begin{array}{c}\text { Entrepreneurial } \\
\text { Framework Conditions }\end{array}$ & Author \& Date & Title of study & Main Objective & Main Findings \\
\hline & $\begin{array}{c}\text { Tengeh and } \\
\text { Mukwarami (2017) }\end{array}$ & $\begin{array}{l}\text { The Growth Challenges of } \\
\text { Native-owned Spaza Shops } \\
\text { in Selected Townships in } \\
\text { South Africa } \\
\text { Intertwining lives and logics: } \\
\text { Household and informal } \\
\text { economies in Cape Town }\end{array}$ & $\begin{array}{l}\text { This study aimed to } \\
\text { understand the hurdles } \\
\text { that prohibit the growth } \\
\text { and development of } \\
\text { locally-owned Spaza } \\
\text { Shops in two prominent } \\
\text { townships } \\
\text { This study draws on the } \\
\text { narratives of local } \\
\text { businesses in an } \\
\text { impoverished Cape Town } \\
\text { township to situate diverse } \\
\text { logics and strategies; their } \\
\text { histories, and aspirations } \\
\text { that shape small business } \\
\text { successes and struggles. }\end{array}$ & $\begin{array}{l}\text { The study finds that } \\
\text { growth is inhibited by a } \\
\text { number of factors but } \\
\text { not limited to: } \\
\text { Competition from non- } \\
\text { South Africans and } \\
\text { large-scale retailers } \\
\text { operating in malls, } \\
\text { crime, lack of } \\
\text { management skills, poor } \\
\text { marketing and, limited } \\
\text { information on } \\
\text { government services. } \\
\text { The study finds that the } \\
\text { informal economy, } \\
\text { instead of being a } \\
\text { vehicle primarily to } \\
\text { maximize profit, forms } \\
\text { more of an integral part } \\
\text { of peoples' lives. This } \\
\text { multifaceted and } \\
\text { embedded analysis } \\
\text { stretches overly narrow } \\
\text { notions of the informal } \\
\text { economy, its limitations } \\
\text { and logics. }\end{array}$ \\
\hline \multirow[t]{3}{*}{$\begin{array}{c}\text { Financial, Education \& } \\
\text { Training }\end{array}$} & (1) & $\begin{array}{l}\text { Factors that hinder the } \\
\text { growth of small businesses in } \\
\text { South African townships }\end{array}$ & $\begin{array}{l}\text { This study too, examined } \\
\text { factors which hinder the } \\
\text { growth of small businesses } \\
\text { in South African } \\
\text { townships. It aimed to } \\
\text { create awareness around } \\
\text { these factors and to } \\
\text { develop guidelines for } \\
\text { Small } \\
\text { Enterprises owners to } \\
\text { promote successful } \\
\text { business enterprises. }\end{array}$ & $\begin{array}{l}\text { The study finds that the } \\
\text { slow growth rate of } \\
\text { small, medium and } \\
\text { micro enterprises can } \\
\text { be attributed partly to } \\
\text { the lack of support they } \\
\text { receive from support } \\
\text { institutions, and partly to } \\
\text { their own internal } \\
\text { weaknesses. } \\
\text { The findings further } \\
\text { reveal that the most } \\
\text { common causes } \\
\text { impeding business } \\
\text { growth are a lack of } \\
\text { legal knowledge, a lack } \\
\text { of funding and a general } \\
\text { lack of business } \\
\text { acumen. }\end{array}$ \\
\hline & $\begin{array}{l}\text { Liedeman et al. } \\
\qquad(2013)\end{array}$ & $\begin{array}{l}\text { Why are foreign-run Spaza } \\
\text { Shops more successful? The } \\
\text { rapidly changing spaza } \\
\text { sector in South Africa. }\end{array}$ & $\begin{array}{c}\text { This article examined the } \\
\text { contrasting business } \\
\text { models in the Spaza Shop } \\
\text { sector, and compares } \\
\text { foreign-run businesses } \\
\text { with South African } \\
\text { businesses. }\end{array}$ & $\begin{array}{l}\text { The study finds that: } \\
\text { Access to finance and } \\
\text { support for non-South } \\
\text { African participants } \\
\text { needs to be investigated } \\
\text { and clear policy } \\
\text { frameworks developed. }\end{array}$ \\
\hline & Meyer et al. (2016) & $\begin{array}{c}\text { Barriers to Small informal } \\
\text { development and } \\
\text { Entrepreneurship: a case of } \\
\text { Emfuleni region }\end{array}$ & $\begin{array}{l}\text { This study aimed at } \\
\text { identifying the importance } \\
\text { of entrepreneurship in the } \\
\text { informal sector and the } \\
\text { barriers that these } \\
\text { entrepreneurs face on a } \\
\text { daily basis in South Africa }\end{array}$ & $\begin{array}{l}\text { The study finds that } \\
\text { most of the informal } \\
\text { businesses are } \\
\text { necessity driven rather } \\
\text { than opportunity driven. } \\
\text { Some of the key barriers } \\
\text { they face are crime, and } \\
\text { lack of service delivery. }\end{array}$ \\
\hline
\end{tabular}


(Table 1). Continued.

\begin{tabular}{|c|c|c|c|c|}
\hline $\begin{array}{c}\text { Entrepreneurial } \\
\text { Framework Conditions }\end{array}$ & Author \& Date & Title of study & Main Objective & Main Findings \\
\hline & Matlala et al. (2014) & $\begin{array}{l}\text { How South African Spaza } \\
\text { Shop Owners Utilize mobile } \\
\text { communication technologies } \\
\text { to run their businesses. }\end{array}$ & $\begin{array}{l}\text { This study investigated } \\
\text { how Spaza Shop owners } \\
\text { in South Africa utilise } \\
\text { mobile communication } \\
\text { technology and evaluated } \\
\text { opportunities created by } \\
\text { the use of mobile } \\
\text { communication devices to } \\
\text { attain a competitive } \\
\text { advantage. }\end{array}$ & $\begin{array}{l}\text { Limited budgets and } \\
\text { lack of financial } \\
\text { resources were cited as } \\
\text { reasons for non- } \\
\text { adoption. }\end{array}$ \\
\hline \multirow[t]{4}{*}{$\begin{array}{c}\text { Commercial and Legal } \\
\text { Structures }\end{array}$} & $\begin{array}{l}\text { Bischof and Woods } \\
\qquad(2013)\end{array}$ & $\begin{array}{l}\text { Micro and small enterprises } \\
\text { and employment creation: } A \\
\text { case study of manufacturing } \\
\text { micro and small enterprises } \\
\text { in South Africa }\end{array}$ & $\begin{array}{l}\text { This study explored } \\
\text { constraints on the job } \\
\text { creation capabilities of } \\
\text { micro and small } \\
\text { enterprises, specifically } \\
\text { focusing on the } \\
\text { consequences of existing } \\
\text { institutional and regulatory } \\
\text { frameworks, on an } \\
\text { investigation of a number } \\
\text { of firms within the } \\
\text { manufacturing sector. }\end{array}$ & $\begin{array}{l}\text { The study finds that } \\
\text { most of the small firms } \\
\text { interviewed were locked } \\
\text { into 'coping mode' and } \\
\text { were extremely reluctant } \\
\text { to expand, which } \\
\text { owners ascribed to } \\
\text { inappropriate regulation, } \\
\text { outright Regulatory } \\
\text { failures and/or poor } \\
\text { labour relations. }\end{array}$ \\
\hline & $\begin{array}{l}\text { Coetzer and Pascarel } \\
\qquad(2014)\end{array}$ & $\begin{array}{l}\text { Last mile delivery in low } \\
\text { income communities: } \\
\text { The Sekulula spaza express } \\
\text { experiment in South Africa. }\end{array}$ & $\begin{array}{l}\text { The aim of this study was } \\
\text { to pilot a business model } \\
\text { (Sekulula Spaza Express) } \\
\text { to deliver goods to informal } \\
\text { traders in Khayelitsha and } \\
\text { Nyanga in Cape Town, } \\
\text { South Africa. }\end{array}$ & $\begin{array}{c}\text { The results of the study } \\
\text { allowed the researchers } \\
\text { to gain a better } \\
\text { understanding of the } \\
\text { dynamics of delivery in } \\
\text { low income communities } \\
\text { in the South African } \\
\text { context. It also identifies } \\
\text { the bottlenecks that are } \\
\text { to be addressed in order } \\
\text { to create a financially } \\
\text { viable business model. }\end{array}$ \\
\hline & Matlala et al. (2014) & $\begin{array}{l}\text { How South African Spaza } \\
\text { Shop Owners Utilize mobile } \\
\text { communication technologies } \\
\text { to run their businesses. }\end{array}$ & $\begin{array}{l}\text { This study investigated } \\
\text { how Spaza Shop owners } \\
\text { in South Africa utilise } \\
\text { mobile communication } \\
\text { technology and evaluated } \\
\text { opportunities created by } \\
\text { the use of mobile } \\
\text { communication devices to } \\
\text { attain a competitive } \\
\text { advantage. }\end{array}$ & $\begin{array}{l}\text { The study finds a high } \\
\text { adoption rate of mobile } \\
\text { communication } \\
\text { technology amongst the } \\
\text { Spaza Shop owners for } \\
\text { communication with } \\
\text { suppliers and } \\
\text { customers. The study } \\
\text { also reports and notes } \\
\text { opportunities lost as a } \\
\text { result of non-adoption. } \\
\text { Limited budgets and } \\
\text { lack of financial } \\
\text { resources were cited as } \\
\text { reasons for non- } \\
\text { adoption. }\end{array}$ \\
\hline & $\begin{array}{l}\text { Barsadien et al. } \\
\qquad(2014)\end{array}$ & $\begin{array}{c}\text { Entrepreneurial Orientation } \\
\text { of Spaza Shop } \\
\text { entrepreneurs; Evidence } \\
\text { from a Study of South African } \\
\text { and Somali Owned Spaza } \\
\text { Shop Entrepreneurs in } \\
\text { Khayelitsha }\end{array}$ & $\begin{array}{l}\text { This study focused on the } \\
\text { role of culture on business } \\
\text { practices and also } \\
\text { entrepreneurial orientation } \\
\text { on business performance. }\end{array}$ & $\begin{array}{l}\text { The study finds that } \\
\text { foreign shop keepers } \\
\text { are more successful } \\
\text { than South Africans } \\
\text { because of the strength } \\
\text { of their social networks } \\
\text { providing them with } \\
\text { access to labour and } \\
\text { capital and the ability to } \\
\text { purchase collectively } \\
\text { and dominate the } \\
\text { market. }\end{array}$ \\
\hline
\end{tabular}


(Table 1). Continued.

\begin{tabular}{|c|c|c|c|c|}
\hline $\begin{array}{c}\text { Entrepreneurial } \\
\text { Framework Conditions }\end{array}$ & Author \& Date & Title of study & Main Objective & Main Findings \\
\hline \multirow[t]{3}{*}{ Physical Infrastructure } & $\begin{array}{l}\text { Bischof and Woods } \\
\qquad \text { (2013) }\end{array}$ & $\begin{array}{l}\text { Micro and small enterprises } \\
\text { and employment creation: } A \\
\text { case study of manufacturing } \\
\text { micro and small enterprises } \\
\text { in South Africa }\end{array}$ & $\begin{array}{l}\text { This study explored } \\
\text { constraints on the job } \\
\text { creation capabilities of } \\
\text { micro and small } \\
\text { enterprises, specifically } \\
\text { focusing on the } \\
\text { consequences of existing } \\
\text { institutional and regulatory } \\
\text { frameworks, looking at a } \\
\text { panel of firms within the } \\
\text { manufacturing sector. }\end{array}$ & $\begin{array}{l}\text { The study finds that } \\
\text { most of these } \\
\text { businesses were } \\
\text { extremely reluctant to } \\
\text { expand due to space } \\
\text { issues. }\end{array}$ \\
\hline & Meyer et al. (2016) & $\begin{array}{c}\text { Barriers to Small informal } \\
\text { development and } \\
\text { Entrepreneurship: a case of } \\
\text { Emfuleni region }\end{array}$ & $\begin{array}{l}\text { This study aimed at } \\
\text { identifying the importance } \\
\text { of entrepreneurship in the } \\
\text { informal sector and the } \\
\text { barriers that these } \\
\text { entrepreneurs face on a } \\
\text { daily basis in South Africa. }\end{array}$ & $\begin{array}{l}\text { The study finds that lack } \\
\text { of vacant land and } \\
\text { premises is a hindrance } \\
\text { in the informal economy } \\
\text { business development. }\end{array}$ \\
\hline & $\begin{array}{l}\text { Chikwendu Ezennia, } \\
\text { Mutambara, and } \\
\text { Indermun (2015) }\end{array}$ & $\begin{array}{c}\text { Challenges Faced by } \\
\text { Foreign-owned Informal } \\
\text { Small Businesses in Durban, } \\
\text { South Africa }\end{array}$ & $\begin{array}{l}\text { The study explored the } \\
\text { significance of the } \\
\text { existence of foreign small } \\
\text { informal enterprises as } \\
\text { well as the encounters of } \\
\text { violent attacks and } \\
\text { generally the social- } \\
\text { economic problems } \\
\text { endured within South } \\
\text { African townships. }\end{array}$ & $\begin{array}{l}\text { The study found there } \\
\text { was a limitation in } \\
\text { infrastructural facilities. }\end{array}$ \\
\hline $\begin{array}{c}\text { Research \& } \\
\text { Development; Innovation }\end{array}$ & Matlala et al. (2014) & $\begin{array}{l}\text { How South African Spaza } \\
\text { Shop Owners Utilize mobile } \\
\text { communication technologies } \\
\text { to run their businesses }\end{array}$ & $\begin{array}{l}\text { This study investigated } \\
\text { how Spaza Shop owners } \\
\text { in South Africa utilise } \\
\text { mobile communication } \\
\text { technology and evaluated } \\
\text { opportunities created by } \\
\text { the use of mobile } \\
\text { communication devices to } \\
\text { attain a competitive } \\
\text { advantage. }\end{array}$ & $\begin{array}{l}\text { The study finds a high } \\
\text { adoption rate of mobile } \\
\text { communication } \\
\text { technology amongst the } \\
\text { Spaza Shop owners in } \\
\text { order to communicate } \\
\text { with suppliers and } \\
\text { customers. The study } \\
\text { also reports and notes } \\
\text { opportunities lost as a } \\
\text { result of non-adoption. } \\
\text { Limited budgets and } \\
\text { lack of financial } \\
\text { resources were cited as } \\
\text { reasons for non- } \\
\text { adoption. }\end{array}$ \\
\hline
\end{tabular}

Content analysis was used to acquire meaning, and analyse the relevance of these journal articles. Usually this method of analysis is used to process written communication enabling data to be grouped into subcategories in the process of identifying meaning and in describing the phenomenon researched (Elo and Kynngas, 2008). There is a misconception that content analysis is used to group words into themes, meaning and/or patterns. This is not the case. Content analysis goes beyond those activities and allows the researcher to understand social reality in a subjective, but scientific manner (Shang, 2017). It is for this reason that the results are tabled, to make it easier for the reader to identify how social reality decisions were reached.
The following scope of review consists of journal articles on township economics, township business dynamics and foreign entrepreneurship success in South African Townships. Fifteen articles were found to be relevant to the study, within the established parameters. The literature investigated comprised of articles pertaining to different effects, and factors of success in the township economy sector, namely violence, failure, education and infrastructure. There is limited in-depth research that provides an interpretative dimension on why small informal businesses owned by South African black entrepreneurs struggle in the township whereas foreign entrepreneurs perform better than their South African counterparts. This view is 


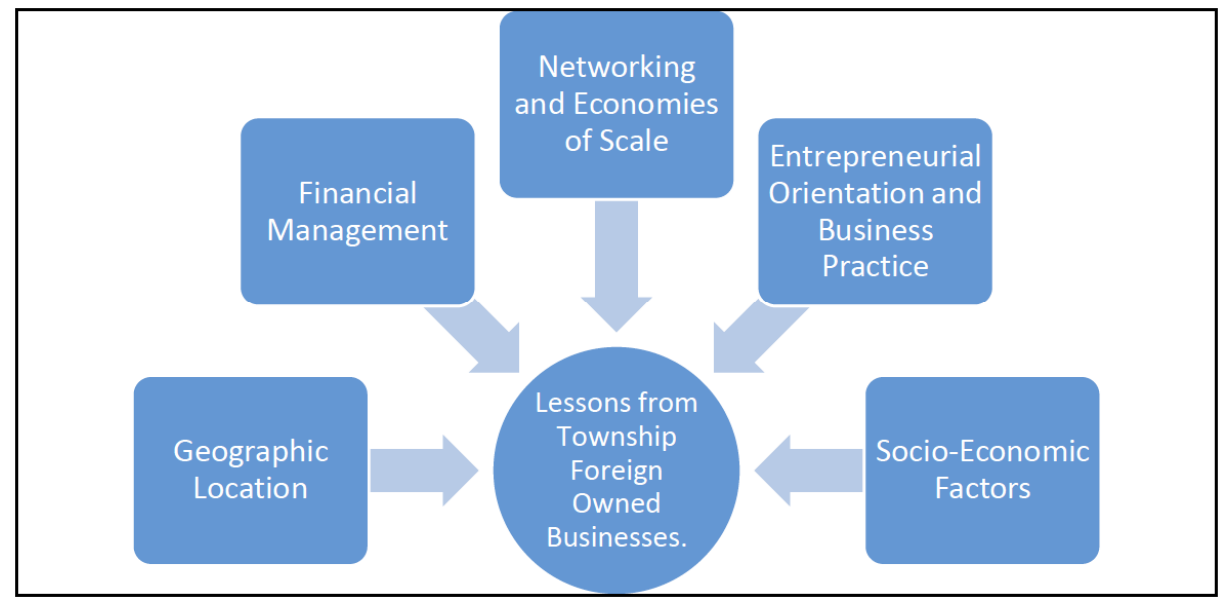

Figure 2: Conceptual Framework: Lessons from Foreign Owned Businesses in Townships.

Source: Authors Own.

supported by Jürgen and Donaldson (2012), who argue that far too limited a scope for research exists on the informal economy to address township business issues in South Africa holistically.

\section{DISCUSSION}

Most of the literature collected links foreign-run informal businesses or Spaza Shops with success traits, and locally owned ones with failure and/or closure. The objective is to address the question posed at the beginning of the study as to why locally owned Spaza Shops underperform when compared to foreign informal businesses with the same produce and similar opportunities. The South Africans owned Spaza shops were found to be more survivalist in their approach to operations and generally smaller than foreign owned shops (Liedeman et al., 2013). This results in the inability of local Spaza Shop owners to compete on price and scale with their foreign Spaza Shop owners.

\section{Networking and Economies of Scale}

A critical attribute of the foreign entrepreneurship community within townships is the formation of consistent clan-based social networks, which South Africans do not participate in. Through these networks, foreign shops make strategic investments, and according to Liedeman et al. (2013), they make group purchases taking advantage of economies of scale in order to access bulk discounts on their products and prices. Foreign shopkeepers' operate on a premise of a co-operative system; supply chain from their wholesalers, forming a large scale operation, a vast pool of labour and diversifying product range they acquire together as different shop owners. Learning strategies on social networks operations, access to labour, capital and collective bargaining practice by foreign owned business can positively contribute to township business models overall Barsadien et al. (2014).

\section{Entrepreneurial Orientation and Business Practices}

It was noted that there was specific differentiation between local and foreign entrepreneurship processes Basardien et al. (2014). Certain characteristics such as risk-taking by foreigners; innovative use of decommissioned containers as stores; competitiveness; and reactiveness form some of these. The level of education, training and entrepreneurial psychology are key to the efficacy of business practices and orientation by foreign Spaza Shop owners. In the literature of Hutchinson and de Beer (2013), the researchers reported a severe lack of adequate literacy and education amongst local vendors. In addition, they revealed deficits in prior practical experience and formal planning, where locals planned only on a day-to-day basis. An absence of business knowledge and functional areas of management were also highlighted. Although these deficiencies are to be expected within an informal trade industry, foreigners seem to have the upper hand on their South African counterparts in all of these aspects. An example of how culture and orientation play a role in their success is the fact that foreigners are essentially away from home and family whilst abroad and it can be argued that their primary focus is therefore on the performance of their business. It could be deduced that they have the time to acquire as much knowledge as possible about legal and commercial 
frameworks whilst learning from their environment, as well as having the ability to learn through formal education. The motivation to open Spaza shops for locals is to augment existing household income, whereas foreigners form and use Spaza shop business models they have created as the main source of income to maintain their livelihood. Charman et al. (2012).

There is a growing need to forgo the stereotypical view that informal businesses do not apply innovation in their operations. These owners are guided by the gaps they perceive in their environment in order to ascertain what services and products to provide for the township market (Fatoki, 2014 and Neves and du Toit, 2012). This is aligned with Shane's (2014:4) description of how innovation and/or technology should be described. He proposes that innovation and technology should encompass 'application of tools, materials processes and techniques to human activity'. This is similar to what is currently taking place in most of these businesses where there has been an accelerated high rise in the use of mobile communication in doing business, this technology now forms part of their supplier and customer communication strategy (Matlala, et. al., 2014).

\section{Geographic Location}

According to Charman et al. (2012) what is common across different townships is a trend in which foreign owned shops are at times situated next to or in close proximity to the locally owned informal shops. The difference is that the foreign owned shops tend to operate from either proper business rental spaces or they erect refurbished containers in areas that are underserved by current retail businesses in the area (Charman et.al., 2012). Most locally owned Spaza shops operate from their own homes. Spatial distribution, on where you physically place a Spaza Shop is an important factor in the success of foreign informal businesses (Charman, et.al., 2012). Foreign shop owners seem to conduct a more in-depth study of the township. They will either rent or erect business structures to trade having studied dynamics, foot traffic and design of a township so that they can place themselves in the most lucrative spaces.

\section{Financial Management}

Lack of financial acumen is a serious challenge for local owners. Studies by Liedeman et. al. (2013), Charman et al. (2012), and Basardien et al. (2014) all highlight financial management as a skill which must be understood and practiced by informal businesses in order to succeed. They agree that this skill is lacking for most local Spaza shop owners. Included in the requisite basket of financial management skills are: record-keeping; financial planning; appropriate use of financial information; efficient management of inventory and cash book maintenance. Basardien et. al. (2014) found that foreigners implemented aspects of these requisites whilst locals did not, resulting in a negative reflection on their financials. Bad business decisions were not avoided. There was a trend with some local Spaza Shops to overinvest or overcapitalise on inventory (Piper \& Yu, 2016). These gaps in financial knowledge and practice contributed significantly to failure. Financial astuteness allows the entrepreneur to make important decisions on business activity and productivity. Hutchinson and de Beer (2013) found that limited knowledge of financial services available to the entrepreneurs was a hindrance, which impeded longterm survival and the development of South African owned informal entities.

\section{Socio-Economic Factors}

Social issues include the pandemic of xenophobia and tensions between South African communities and foreign shop owners. Trade competition has sparked violent tensions and conflicts between foreign nationals and South African citizens (Mafukata, 2015). This affects all businesses in the township. Poor health and diseases impact on entrepreneurial participation. (Chao, Szrek, Pereira, \& Pauly, 2010 and Kunene \& Dyili, 2014). Where there is a wide network, as found in foreign owned entities, businesses have a succession plan to deal with this. As mentioned, education and business acumen are pivotal to the failure of locally owned Spaza Shops. Social considerations and the understanding of these dynamics, create an opportunity to learn, and understand the diverse objectives of entrepreneurial activity in townships (Fatoki, 2014).

\section{RECOMMENDATIONS}

Basic education needs to embed all the necessary basic entrepreneurship skills so that many citizens, are empowered with adequate knowledge on how to run businesses. Government intervention should also focus on subsidising training and implementing development programmes in the informal economy. Most of these programmes should be geared towards the empowerment of women who make up the majority of 
locally owned Spaza shops. Business owners have a responsibility to ensure that they gain necessary business experience and/or mentorship, and they must strive to constantly improve their business knowledge.

Conflict between South African shopkeepers and non- South African entrepreneurs has been less about nationality and more about differing business practices and competitiveness. Government, and specifically the Department of Home Affairs, should ensure that relations between non-South African shop owners and locals remains stable and amicable.

Microeconomic and entrepreneurial centres or hubs for learning need to be established in order to foster a culture of successful South African entrepreneurs and assist business owners in overcoming their challenges. Furthermore, a promotion of networking between informal South African businesses is instrumental for growth and development to take place in communities and businesses.

\section{FUTURE RESEARCH AND LIMITATIONS OF THE STUDY}

There is a need to conduct a triangulation study to get a systematic view of the phenomenon. This research is exploratory, however, it allows for more indepth analysis into practice and implementation of strategies in order to assist locally owned businesses in the townships.

An important area to research is the link that the informal sector has with indigenous knowledge systems of doing business, specifically Ubuntu Management Principles, where business owners work together. Coalition and collaboration between South African and foreign business owners in the township is one aspect of possible growth that has not been explored by researchers in the field. It would be important to ascertain if such a possibility could increase the potential of locally owned Spaza Shops within the definition of the country's economy.

\section{CONCLUSION}

South Africans have reacted in various ways to the transformation of the informal economy with the increasing presence of foreign owned enterprises. Overall, South African consumers have enjoyed the competitive reduction in pricing and better services from foreign shops. On the other hand, dramatic hostility from South African shopkeepers towards foreign owned competitors prevails in the form of xenophobic attacks. Survivalist home-based enterprises of local South Africans help alleviate poverty and unemployment, and serve as important income generating models for township communities. There are therefore notable lessons that local Spaza Shop owners can learn from foreign Spaza Shop owners.

\section{REFERENCES}

Abdi, C.M. 2011 Moving Beyond Xenophobia: Structural Violence, Conflict and encounter with the 'other' Africans. Development Southern Africa, 28(5): Special Issue-Development, inequality and social justice in Southern Africa, 691-704. https://doi.org/10.1080/0376835X.2011.623916

Basardien, F., Parker, H., Bayat, M., Friedrich, C., and Appoles, S. 2014. Entrepreneurial Orientation of Spaza Shop Entrepreneurs Evidence From a Study of South African and Somali Owned Spaza Shop Entrepreneurs in Khayelitsha. Singaporean Journal of Business Economics and Management Studies, 2(10), 45-61. https://doi.org/10.12816/0006774

Bischoff, C., and Woods, G. 2013 Micro and Small Enterprises and employment creation: A Case Study of Manufacturing Micro and Small Business Enterprises in South Africa. Development South Africa, 30(4-05), 564-579. https://doi.org/10.1080/0376835X.2013.817303

Chao, L., Szrek, H., Pereira, N., and Pauly, M. 2010. Too Sick to Start: Entrepreneur's Health and Business Entry in Townships around Durban, South Africa. Journal of Developmental Entrepreneurship, 15(2), 231-242. https://doi.org/10.1142/S108494671000152X

Charman, A., Petersen, L., and Piper, L. 2012. From Local Survivalist to Foreign Entrepreneurship: The Transformation of the Spaza Sector in Delft, Cape Town. Transformation 78, 1(1), 47-73. https://doi.org/10.1353/trn.2012.0035

Chikwendu Ezennia, J., Mutambara, E., \& Indermun, V. 2015 Challenges Faced by Foreign-owned Informal Small Businesses in Durban, South Africa. Journal of Sustainable City and Society, 2(1), 1-21

Coetzer, P. \& Pascarel, N, 2014. Last Mile Delivery in Low Income Communities: The Sekulula Spaza Express Experiment in South Africa. The Journal of Field Actions. Special Issue 12.

Elos, S., \& Kynngas, H. 2008. The Qualitative Content Analysis Process. JAN Research Methodology, 62(1), 107-115. https://doi.org/10.1111/j.1365-2648.2007.04569.x

Fatoki, O. 2014. Immigrant Entrepreneurship in South Africa: Current Literature and Research Opportunities. Journal of Social Science, 40(1), 1-7. https://doi.org/10.1080/09718923.2014.11893297

Fourie, F. 2018. Creating Jobs, Reducing Poverty: Why the Informa Sector Should be Taken Seriously and Enabled Properly. Econ3X3 Retrieved 3 May 2018, from http://www.econ3×3. org/article/creating-jobs-reducing-poverty-i-why-informalsector-should-be-taken-seriously-and-enabled

Hartnack, A., and Liedeman, R. 2017. Factors Contributing to the Demise of Informal Enterprises: Evidence from a Cape Township. Econ3x3. Retrieved 11 May 2017, from http://www.econ3x3.org/sites/default/files/articles/Hartnack\% $20 \% 26 \% 20$ Liedeman $\% 202017 \% 20$ Reasons $\% 2$ for $\% 20$ infor mal\%20business\%20failure.pdf.

Hutchinson, M., and de Beer, M. 2013. An Exploration of Factors that Limit the Long-Term Survival and Development of Micro and Survivalist Enterprises: Empirical Evidence from the Informal Economy in South Africa. Mediterranean Journal of Social Sciences, 4(13), 237-245

https://doi.org/10.5901/mjss.2013.v4n13p237 
Jurgens, U., and Donaldson, R. 2012. A Review of Literature on Transformation Processes in South African Townships. Urban Forum, 1-11. https://doi.org/10.1007/s12132-012-9149-x

Liedeman, R., Charman, A., Piper, L., and Peterson, L. 2013. Why are Foreign-run Spaza Shop s More Successful? The Rapidly Changing Spaza Sector in South Africa. Econ3x3. Retrieved 11 May 2017, from http://www.econ3x3.org/

Ligthelm, A. 2011. Survival Analysis of Small Informal Businesses in South Africa, 2007-2010. Eurasian Business Review, 2(1), 160-179.

Mafukata, M. 2015. Tracing Evidence of Xenophobic Tensions and Conflicts amongst Informal Trader Foreign Nationals and Informal Village-Based Entrepreneur South Africans. The International Journal of Business \& Management, 3(1), 5166.

Matlala, R., Shambere, R, and Lebombo, M. 2014. How South African Spaza Shop owners utilise mobile communication technologies to run their businesses. European Scientific Journal, 10(25), 180-195.

Mbonyane, B., \& Ladzani, W. 2011. Growth Small Business Factors that Hinder the Growth of Small Businesses in South African Townships. European Review, 23(6), 550-560. https://doi.org/10.1108/09555341111175390

Meyer, N., Meyer, D.F., and Molefe, K, N. 2016. Small Informal Development. Polish Journal of Management, 13(1). https://doi.org/10.17512/pims.2016.13.1.12

Neves, D., and du Toit, A. 2012. Money and Sociality in Southern Africans Informal Economy. Africa, 82(1): Special IssuePopular Economies in South Africa. https://doi.org/10.1017/S0001972011000763

Oldfield, S. 2014. Intertwining Lives and logics: Household and Informal. Urban Izziviz, S36-S46. https://doi.org/10.5379/urbani-izziv-en-2014-25-supplement$\underline{003}$
Piper, L., and Yu, D. 2016. Deconstructing 'the foreigner': The limits of Citizenship for Explaining Price Competition in the Spaza Sector in South Africa, 33(5), 658-676. https://doi.org/10.1080/0376835X.2016.1203758

Preisendorfer, P., Bitz, A., and Bezuidenhout, F. 2012. Business Start-Ups and Their Prospects of Success in South African Townships. South African Review of Sociology, 43(3), 1-23. https://doi.org/10.1080/21528586.2012.727542

Tengeh, R., and Mukwarami, J. 2017. The Growth Challenges of Native Owned Spaza Shops in Selected Townships in South Africa. International Journal of Applied Business and Economic Research, 15(22), 61-74.

The Sustainable Livelihoods Foundation 2012. The informal economy of township Spaza Shops. www.livelihoods.org

Retrieved 11 May 2017, from http://livelihoods.org.za/wpcontent/uploads/2015/05/The-Informal-Economy-ofTownship-Spaza-Shops-.pdf.

Shane, S.A. 2014. Technology Strategy for Managers and Entrepreneurs. Pearson Education Limited. Essex, London. $1^{\text {st }}$ Ed.

Symanowitz, C. 2013. Is South Africa's Labour Law Killing Entrepreneurship? www.colettesymanowitz.com. Retrieved 11 May 2017, from https://colettesymanowitz.com/ 2013/02/05/is-south-africas-labour-law-killingentrepreneurship/

The World Bank 2014. Economics of South African Townships Special Focus on Diepsloot. A World Bank Study, 1(1), 1-26

Van Aardt, I., Barros, M., Clearence, W., Janse van Rensberg, L. Radipere, S., Rankhumise, E.M., Venter, E. and Visser, D.J. 2016. Principles of Entrepreneurship and Small Business Management (2nd Ed) Cape Town: Oxford University Press

Zhang, Y. 2017. Qualitative Analysis of Content. In Widemuth, B.M (ed). Social Research Methods to Questions in Information and Library Science. Libraries unlimited. Santa Barbara, California. $1^{\text {st }}$ Ed.

DOI: https://doi.org/10.6000/1929-7092.2019.08.118

(c) 2019 Lamb et al.; Licensee Lifescience Global.

This is an open access article licensed under the terms of the Creative Commons Attribution Non-Commercial License (http://creativecommons.org/licenses/by-nc/3.0/) which permits unrestricted, non-commercial use, distribution and reproduction in any medium, provided the work is properly cited. 